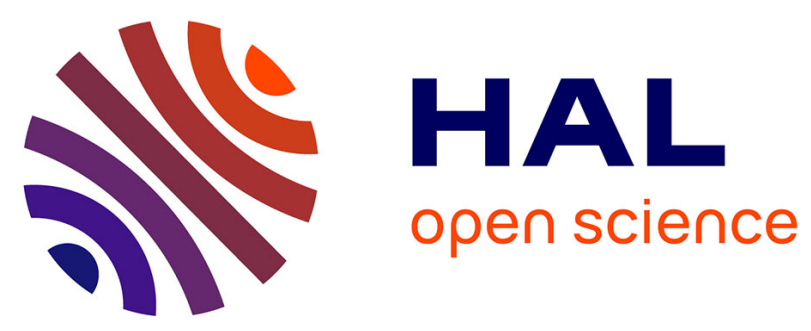

\title{
The replacement of a phenol group by an aniline or acetanilide group enhances the cytotoxicity of 2-ferrocenyl-1,1-diphenyl-but-1-ene compounds against breast cancer cells
}

Pascal Pigeon, Siden Top, Ouardia O. Zekri, Elisabeth A. Hillard, Anne A. Vessieres, M.A. Plamont, Olivier O. Buriez, Eric E. Labbé, Michel Huché, Sultana S. Boutamine, et al.

\section{- To cite this version:}

Pascal Pigeon, Siden Top, Ouardia O. Zekri, Elisabeth A. Hillard, Anne A. Vessieres, et al.. The replacement of a phenol group by an aniline or acetanilide group enhances the cytotoxicity of 2ferrocenyl-1,1-diphenyl-but-1-ene compounds against breast cancer cells. Journal of Organometallic Chemistry, 2009, 694, pp.895-901. 10.1016/j.jorganchem.2008.11.035 . hal-00376093

\section{HAL Id: hal-00376093 https://hal.science/hal-00376093}

Submitted on 14 Oct 2019

HAL is a multi-disciplinary open access archive for the deposit and dissemination of scientific research documents, whether they are published or not. The documents may come from teaching and research institutions in France or abroad, or from public or private research centers.
L'archive ouverte pluridisciplinaire HAL, est destinée au dépôt et à la diffusion de documents scientifiques de niveau recherche, publiés ou non, émanant des établissements d'enseignement et de recherche français ou étrangers, des laboratoires publics ou privés. 
The replacement of a phenol group by an aniline or acetanilide group enhances the cytotoxicity of 2-ferrocenyl-1,1-diphenyl-but-l-ene compounds against breast cancer cells

\author{
Pascal Pigeon ${ }^{\text {a }}$, Siden Top ${ }^{\text {a }}$, Ouardia Zekri ${ }^{\text {a,c }}$, Elizabeth A. Hillard ${ }^{\text {a }}$, Anne Vessières ${ }^{\text {a, }}$, \\ Marie-Aude Plamont ${ }^{\mathrm{a}}$, Olivier Buriez ${ }^{\mathrm{b}}$, Eric Labbé ${ }^{\mathrm{b}}$, Michel Huché ${ }^{\mathrm{a}}$, Sultana Boutamine ${ }^{\mathrm{c}}$, \\ Christian Amatore ${ }^{\mathrm{b}}$, Gérard Jaouen ${ }^{\mathrm{a}}$ \\ a Laboratoire de Chimie et Biochimie des Complexes Moléculaires, UMR CNRS 7576, Ecole Nationale \\ Supérieure de Chimie de Paris, 11 rue Pierre et Marie Curie, 75231 Paris Cedex 05, France \\ ${ }^{\mathrm{b}}$ Ecole Normale Supérieure, Département de Chimie, UMR CNRS-ENS-UPMC 8640, 24 rue Lhomond, 75231 \\ Paris Cedex 05, France \\ ${ }^{\mathrm{c}}$ Université des Sciences et de la Technologie Houari Boumediene, Faculté de Chimie, BP32, El Alia Bab \\ Ezzouar, Alger, Algeria
}

Keywords: Bioorganometallic chemistry ; Ferrocene ; Anti-cancer drugs ; Breast cancer ; Iron

* Corresponding author. Tel.: +33014427 67 29; fax: +33 0143260061.

E-mail address: a-vessieres@enscp.fr (A. Vessières).

\begin{abstract}
We have previously shown that conjugated ferrocenyl $p$-phenols show strong cytotoxic effects against both the hormone-dependent MCF-7 and hormone-independent MDA-MB-231 breast cancer cell lines, possibly via oxidative quinone methide formation. We now present a series of analogous amine and acetamide compounds: 2-ferrocenyl-1-(4-aminophenyl)-1-phenylbut-1-ene $(Z+E-2), 2$-ferrocenyl-1-(4- $N$-acetylaminophenyl)-1-phenyl-but-1-ene (Z-3), and their corresponding organic molecules 1-(4-aminophenyl)-1,2-bis-phenyl-but-1-ene $(Z+E-4)$ and 1-(4- $N$-acetamidophenyl)-1,2-bis-phenyl-but-1-ene $(Z+E-5)$. All of the compounds have adequate relative binding affinity values for the estrogen receptor; between $2.8 \%$ and $5.7 \%$ for $\mathrm{ER} \alpha$, and between $0.18 \%$ and $15.5 \%$ for $\mathrm{ER} \beta$, as well as exothermic ligand binding in in silico ER docking experiments. Compounds $\mathbf{2}$ and $\mathbf{3}$ show dual estrogenic/cytotoxic activity on the MCF-7 cell line; they are proliferative at low concentrations $(0.1 \mu \mathrm{M})$ and antiproliferative at high concentrations $(10 \mu \mathrm{M})$. On the MDA-MB-231 cell line, the ferrocenyl complexes $\mathbf{2}$ and $\mathbf{3}$ are antiproliferative with $\mathrm{IC}_{50}$ values of $0.8 \mu \mathrm{M}$ for $\mathbf{2}$ and 0.65 $\mu \mathrm{M}$ for $\mathbf{3}$, while the purely organic molecules $\mathbf{4}$ and $\mathbf{5}$ show no effect. Electrochemical experiments suggest that both $\mathbf{2}$ and $\mathbf{3}$ can be transformed to oxidized quinoid-type species, analogous to what had previously been observed for the ferrocene phenols.
\end{abstract}

\title{
1. Introduction
}

Compounds that can be activated by the redox environment of a cellular target to produce reactive oxygen species (ROS) [1] or reactive intermediates [2] have recently gained much attention, particularly in cancer treatment [3]. For example, compounds containing phenol moieties, such as resveratrol, can modify the oxidative stress level of the cell to cause necrosis and apoptosis [4,5]. Tamoxifen (Chart 1), a leading treatment for all phases of hormonedependent breast cancer [6], also shows a mild non-genomic cytotoxic activity, which has been attributed to its aromatic hydroxylation and biooxidation to radical or electrophilic species [7]. We have been studying a series of conjugated ferrocenyl phenols, which show antiproliferative effects in vitro on both hormone-independent (ER-) and hormone-dependent $(\mathrm{ER}+)$ breast cancer cells [8,9] and in vivo against glioma [10]. Structure activity relationship studies have demonstrated the importance of the presence of a ferrocene group [11,12], a $p$ - 
phenol [13], and a $\pi$-system linking the two moieties [14], for a strong cytotoxic activity in vitro. Electrochemical experiments have suggested that the active species in cell cultures could be a quinone methide, which may be formed via an intramolecular oxidation of the phenol moiety by the in situ-generated ferricenium cation [15]. Other investigators have also shown a correlation between the toxicity of a tamoxifen-ferrocene conjugate and the production of ROS [16]. Ferricenium-promoted intramolecular electron transfer in phenolic systems has been recognized [17-21], although our work is the first application of this mechanism to oxidation-activated drug development.

According to the proposed mechanism of activation [15], we expect that the substitution of the hydroxyl group by other protic and oxidizable functionalities should retain the molecules' cytotoxic properties and specific electrochemical signature. However, in a previous study, we found that the dithioacetyl prodrug analog 1a (Chart 1) displayed only proliferative effects on hormone-dependent breast cancer cells (MCF-7), and no (cytotoxic) effect on hormoneindependent breast cancer cells (MDA-MB-231) [22]. This was in marked contrast to the diacetoxy compound, $\mathbf{1 b}$, which showed cytotoxic effects similar to that of the diphenol 1c, suggesting that intracellular hydrolysis of the compound to the active hydroxylated species takes place. As thioesterases have been isolated from breast cancer cells [23], we attributed this lack of activity not to the protection of the thiol, but to the poor overlap between the $3 p \mathrm{~S}$ and $2 \mathrm{p} \mathrm{C}$ atomic orbitals, which disfavors thioquinone methide formation.
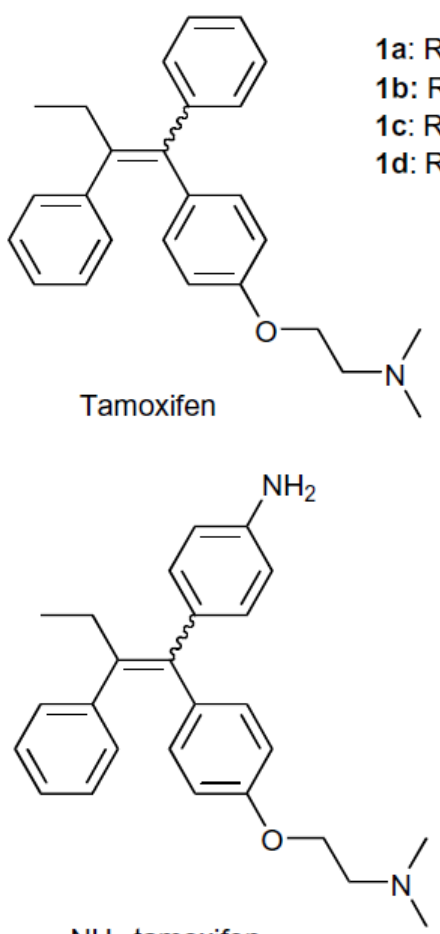

$\mathrm{NH}_{2}$-tamoxifen

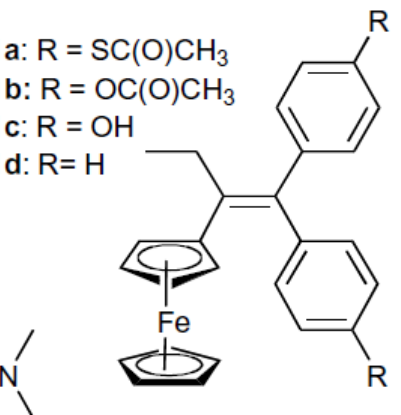

1

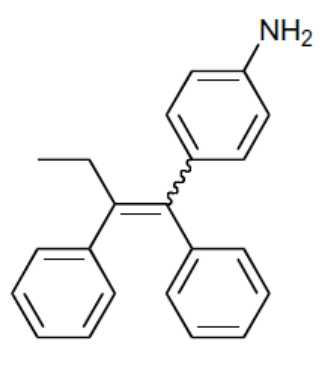

$(Z+E)-4$

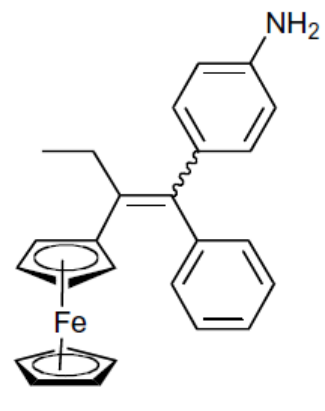

$(Z+E)-2$

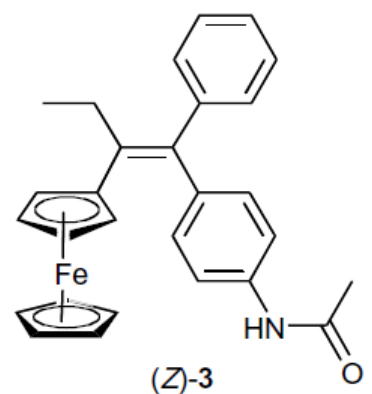

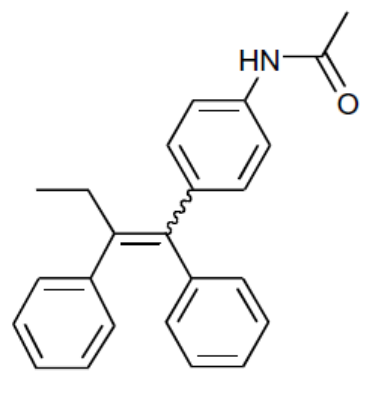

$(Z+E)-5$

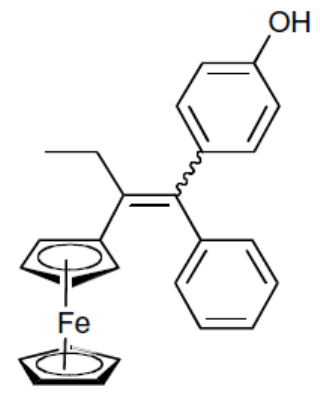

$(Z+E)-6$

Chart 1. The breast cancer drug tamoxifen, the amino derivative of tamoxifen, previously studied ferrocene complexes $\mathbf{1 a - 1 d}$ and $\mathbf{6}$ and new compounds $\mathbf{2}-\mathbf{5}$.

We now investigate the synthesis, cell proliferation effects, and electrochemical behavior of the ferrocenyl aniline $\mathbf{2}$ and acetanilide $\mathbf{3}$ shown in Chart 1, particularly as compared to the cytotoxic monophenolic analog 6 [8]. We have also studied their purely organic counterparts, 4 and 5 to evaluate the importance of the ferrocenyl moiety. These later compounds are relevant, in that the literature on the biological effects of aryl amines or amides based on the tamoxifen or triphenylethylene skeleton is scarce; to the best of our knowledge, only one 
study on the uterotrophic effects of the amino derivative of tamoxifen (Chart 1) has been carried out [24].

\section{Results and discussion}

\subsection{Preparation of compounds}

The synthesis of the organometallic compounds was based on a McMurry cross-coupling reaction, the method we commonly use to form alkenes from the reaction of two ketones in the presence of $\mathrm{TiCl}_{4} / \mathrm{Zn}$ [25-27]. Compound $\mathbf{2}$ was synthesized as a mixture of $Z$ and $E$ isomers via the reaction between propionyl ferrocene and 4-aminobenzophenone, as previously reported [28]. The moderate yield $(26 \%)$ is consistent with the previously observed low activity of aminobenzophenone in McMurry reactions [29]. The $Z$ and $E$ isomers of 2 could not be separated using preparative HPLC, and thus the mixture of $(Z+E)-\mathbf{2}$ was used in all further experiments. Similarly, its organic analog 4 was synthesized by a reaction between propiophenone and aminobenzophenone as a mixture of $Z$ and $E$ isomers in $38 \%$ yield (see Scheme 1).

An alternative pathway via a coupling reaction between propionyl ferrocene or propiophenone and 4-nitrobenzophenone also gave access to $\mathbf{2}$ and $\mathbf{4}$. Originally we used this reaction in an attempt to synthesize the corresponding nitro species, but found that an in situ reduction of the nitro group to an amino group furnished $\mathbf{2}$ and $\mathbf{4}$. However, depending on the batch of 4-nitrobenzophenone used, the yield of the reaction varied significantly from high $(>50 \%)$ to poor.

Treating $\mathbf{2}$ with acetyl chloride and pyridine gave $\mathbf{3}$ as a mixture of $Z$ and $E$ isomers (60/40) in 91\% yield, as shown in Scheme 2. The $Z$ isomer was isolated by fractional crystallization and all further tests were performed with the pure isomer. Compound $\mathbf{5}$ was similarly synthesized from 4 in $81 \%$ yield as a mixture of $Z$ and $E$ isomers $(85 / 15)$.

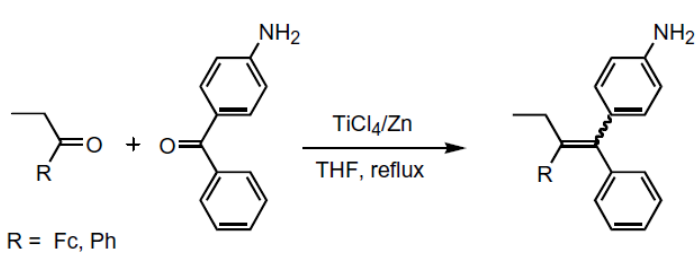

$(Z+E)-2 ; \mathrm{R}=\mathrm{FC}$ $(Z+E)-4 ; \mathrm{R}=\mathrm{Ph}$

Scheme 1. Synthesis of the ferrocenyl and phenyl aniline derivatives $\mathbf{2}$ and $\mathbf{4}$.
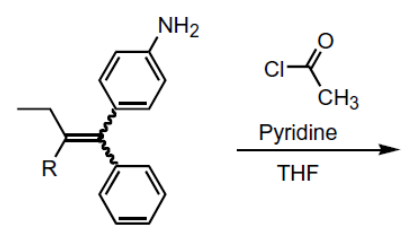

$(Z+E)-2 ; \mathrm{R}=\mathrm{FC}$ $(Z+E)-2 ; R=F C$
$(Z+E)-4 ; R=P h$

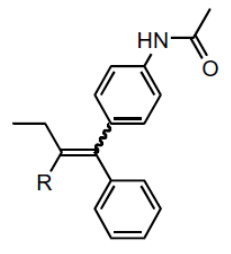

$(Z+E)-3 ; \mathrm{R}=\mathrm{FC}$ $(Z+E)-5 ; \mathrm{R}=\mathrm{Ph}$

Scheme 2. Synthesis of the ferrocenyl and phenyl acetanilide derivatives $\mathbf{3}$ and $\mathbf{5}$.

\subsection{Biological studies}

2.2.1. Determination of the relative binding affinity (RBA) values of the compounds for the two forms of estrogen receptors (ER $\alpha$ and $E R \beta$ )

The RBA values obtained for the new compounds are given in Table 1 . The values found for the ferrocenyl aniline and acetanilide derivatives $\mathbf{2}$ and $\mathbf{3}$ on ER $\alpha$ were only slightly lower than that found for the ferrocenyl monophenol $6(\mathrm{RBA}=4.6 \%)$. This is quite surprising for molecules having no phenol group, which is considered to be essential for ER recognition [30]. Although all compounds have RBA values on the same order of magnitude, the purely organic compounds $\mathbf{4}$ and $\mathbf{5}$, lacking the bulky ferrocene group, have slightly higher affinities for ER $\alpha$. Interestingly, both $\mathbf{2}$ and $\mathbf{4}$ showed a greater affinity for ER $\alpha$ than that found for the amino derivative of tamoxifen $(0.2 \%)$, evidently due to the absence of the amino side-chain 
[24]. The binding affinities for ER $\beta$ are much more variable than for ER $\alpha$, with the organic compounds showing significantly higher values than the ferrocenyl compounds. Nonetheless, all compounds have non-zero RBA values, and thus would be expected to interact with the ERs.

\section{Table 1}

Relative binding affinity (RBA) of the compounds on the two isoforms of the estrogen receptor (ER $\alpha$ and ER $\beta$ ) and $\mathrm{IC}_{50}$ values for the compounds on hormone-independent breast cancer cells, MDA-MB-231.

\begin{tabular}{llll}
\hline Compound & \multicolumn{2}{l}{ RBA $(\%)$} & $\mathrm{IC}_{50}[\mu \mathrm{M}]$ \\
\cline { 2 - 3 }$(Z+E)-\mathbf{2}$ & $\mathrm{ER \alpha}$ & $\mathrm{ER} \beta$ & \\
$(Z)-3$ & $2.8 \pm 0.1$ & $1.08 \pm 0.07$ & $0.8 \pm 0.1$ \\
$(Z+E)-\mathbf{4}$ & $3.5 \pm 0.3$ & $0.18 \pm 0.02$ & $0.65 \pm 0.03$ \\
$(Z+E)-\mathbf{5}$ & $7 \pm 0.3$ & $15.5 \pm 2.5$ & Not toxic at $1 \mu \mathrm{M}$ \\
$(Z+E)-\mathbf{6}$ & $5.7 \pm 0.1$ & $7.7 \pm 0.8$ & Not toxic at $1 \mu \mathrm{M}$ \\
\hline
\end{tabular}

${ }^{\mathrm{a}}$ Value from Ref. [8].

${ }^{\mathrm{b}}$ Value from Ref. [13].

\subsubsection{Molecular modeling of receptor interactions}

Molecular docking experiments using the crystal structure of ER $\alpha$ crystallized with DES (pdb erd.ent) [31], and of ER $\beta$ crystallized with 5,11-cis-diethyl-5,6,11,12tetrahydrochrysene-2,8-diol (THC) (pdb 112j.ent) [32] were performed. Only the amino acids that constitute the wall of the cavity have been retained. The DES or THC molecules were removed from the cavity and replaced successively with the different bioligands. Energy minimization was then carried out using Merck molecular force field (MMFF). All the heavy atoms of the amino acids of the cavity wall were then immobilized and the side chain of His524 for ER $\alpha$ and His475 for ER $\beta$ were liberated. This allowed the ideal positions of the bioligands to be determined. Quantum mechanical semi-empirical PM3 methods were then used to determine the affinity of the bioligands for the cavity. This requires calculation of the energies of bioligand-cavity group, of the cavity itself, and of the ligand, the latter two in the conformations they had in the molecular assemblies to give the $\Delta \mathrm{r} H^{\circ}$ enthalpy variations of the reactions: bioligand + cavity $\rightarrow$ molecular assembly (Table 2). For all compounds, binding with both isoforms of the ER is thermodynamically favored, as evidenced by the negative enthalpy of formation for the ligand-receptor complex.

Table 2

Enthalpy variation values for the bioligand docked into ER $\alpha$ and $\mathrm{ER} \beta$.

\begin{tabular}{lll}
\hline Compound & $\Delta \mathrm{r} H^{\circ}\left(\mathrm{kcal} \mathrm{mol}^{-1}\right)$ & \\
\cline { 2 - 3 } & $\mathrm{ER} \alpha$ & $\mathrm{ER} \beta$ \\
\hline$(Z)-\mathbf{2}$ & -17.5 & -17.3 \\
$(E)-\mathbf{2}$ & -16.4 & -31.1 \\
$(Z)-\mathbf{3}$ & -16.5 & -16.7 \\
$(Z)-\mathbf{4}$ & -13.3 & -8.4 \\
$(Z)-\mathbf{5}$ & -13.5 & -13.2 \\
$(E)-\mathbf{5}$ & -8.8 & -10.3 \\
\hline
\end{tabular}

Fig. 1 shows $(E)-2$ in the cavity of $\mathrm{ER} \alpha$. The $\mathrm{NH}_{2}$ group forms a hydrogen bond with the residues Glu353 and Arg394. On the other side of the molecule the iron atom of the ferrocene 
group interacts with His524. This triple anchorage demonstrates the good association of this isomer with the cavity.

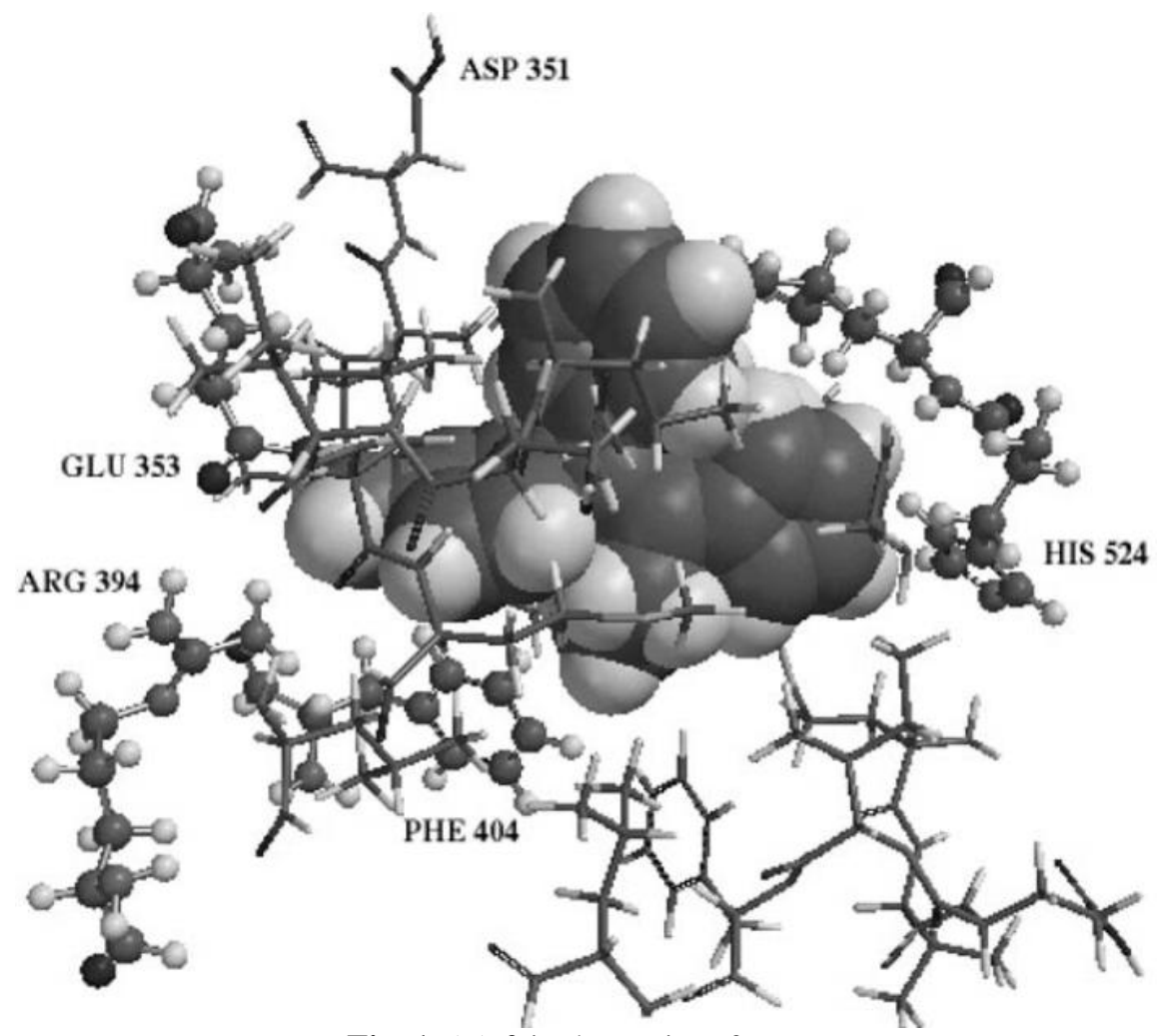

Fig. 1. (E)-2 in the cavity of ER $\alpha$.

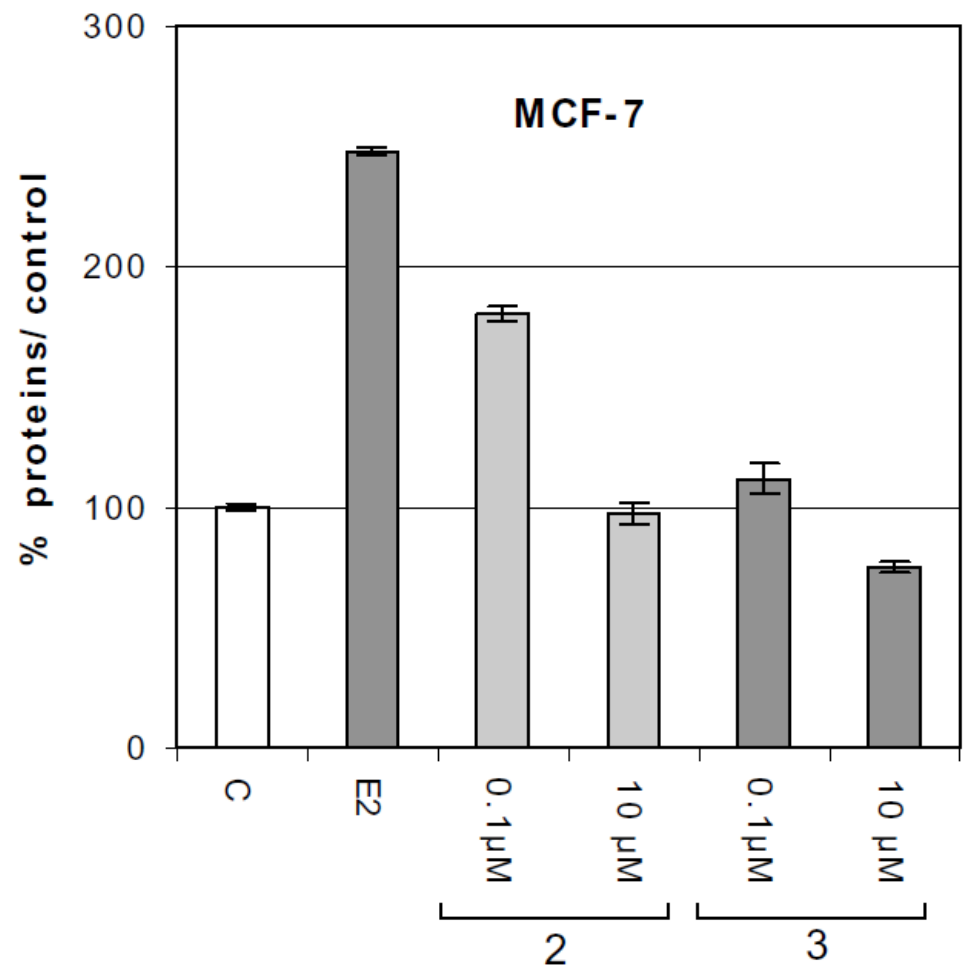

Fig. 2. Effect of estradiol $\left(\mathrm{E}_{2}, 10 \mathrm{nM}\right)$, ferrocenyl aniline $\mathbf{2}$ and ferrocenyl acetanilide $\mathbf{3}$ at low $(0.1 \mu \mathrm{M})$ and high $(10 \mu \mathrm{M})$ concentrations on MCF-7 cells (hormone-dependent breast 
cancer cells) after 5 days of culture. Non-treated cells are used as the control (C). Representative data of one experiment performed twice with similar results (six measurements \pm confidence limit; $P=0.1, t=1.895$ ).

\subsubsection{Effect on hormone-dependent breast cancer cells $M C F-7$}

The effect of 2 and $\mathbf{3}$ on MCF-7 cells is shown on Fig. 2. At the low concentration of 0.1 $\mu \mathrm{M}, 2$ showed a marked proliferative effect while 3 was only slightly proliferative. At the high concentration of $10 \mu \mathrm{M} 2$ had almost no effect while $\mathbf{3}$ gave rise to a moderate antiproliferative effect. It should be mentioned that the experimental conditions used (cell medium without phenol red, an agent normally used for MCF-7 cell culture, but containing an impurity known to be estrogenic) was chosen to favor the expression of the estrogenic component of the tested molecules. However, the estrogenic effects are not consistent with the observed RBA values, which suggest that $\mathbf{3}$, with a stronger binding affinity, should be more estrogenic than 2. This is because the observed effect is actually the net result of the estrogenic (proliferative) effect which is expressed at low concentrations, combined with the cytotoxic (antiproliferative) effect which begins to appear at higher concentrations. The observed results are consistent with the higher cytotoxicity of $\mathbf{3}$ compared with $\mathbf{2}$ (vide infra).

\subsubsection{Effect on hormone-independent breast cancer cells MDA-MB-231}

On MDA-MB-231 2 and 3 showed a strong antiproliferative effect (Fig. 3) with $\mathrm{IC}_{50}$ values of 0.8 and $0.65 \mu \mathrm{M}$, respectively (Table 1). Remarkably, these compounds are more cytotoxic than the ferrocenyl monophenol $\mathbf{6}$ and approach the antiproliferative potency of the previously reported ferrocenyl diphenol $1 \mathrm{c}\left(\mathrm{IC}_{50}=0.6 \mu \mathrm{M}\right)$ [33]. Consequently, they join the group of the ferrocenyl derivatives having the lowest $\mathrm{IC}_{50}$ values $(<1 \mu \mathrm{M})$ found so far [9]. It should be noted that the unsubstituted ferrocenyl compound 1d showed no effect even at concentrations as high as $10 \mu \mathrm{M}$, demonstrating the participation of the functional groups in the cytotoxic activity [13]. Interestingly, neither the organic amine $\mathbf{4}$ nor the acetylamide $\mathbf{5}$ was cytotoxic at $1 \mu \mathrm{M}$, although the oxidative metabolism of aromatic amines is known to produce toxic species [34,35], including in breast cancer cells [36]. Nonetheless, in our experiments, the presence of the ferrocenyl group was essential for a strong cytotoxic effect.

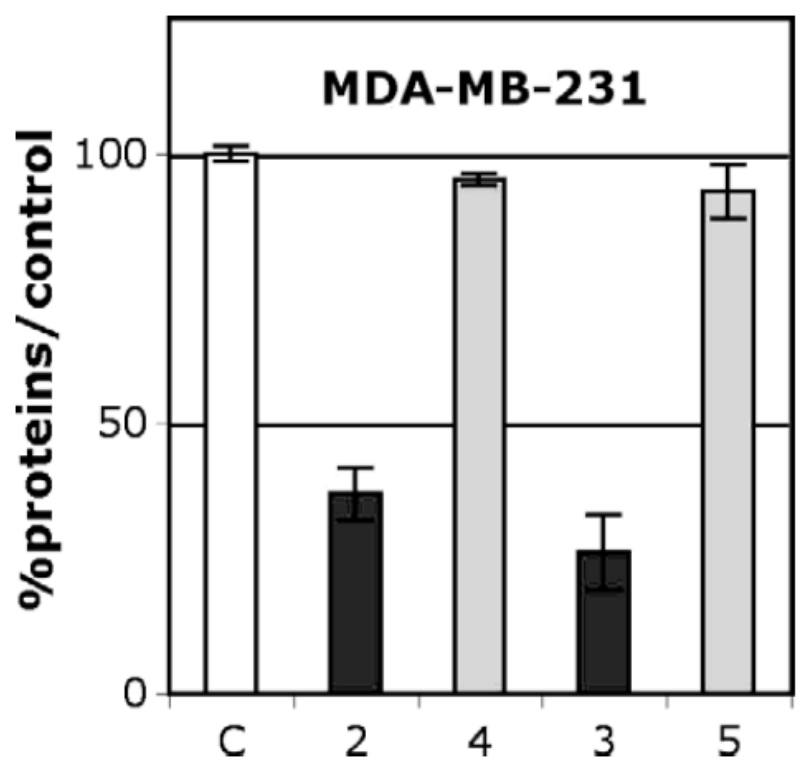

Fig. 3. Effect of $1 \mu \mathrm{M}$ of the ferrocenyl aniline $\mathbf{2}$ and acetanilide $\mathbf{3}$ and of their corresponding purely organic molecules $\mathbf{4}$ and $\mathbf{5}$ on the growth of MDA-MB-231 (hormone-independent breast cancer cells) after 5 days of culture. Non-treated cells are 
used as the control (C). Representative data of one experiment performed twice with similar results (six measurements \pm confidence limit; $P=0.1, t=1.895$ ).

Xenobiotics are metabolized in vivo, generally to more polar, water-soluble products [37]. Hydrolyzing enzymes as esterases and amidases, are ubiquitous, [38] including in breast cancer cells [39-44]. These enzymes compete with arylamine $\mathrm{N}$-acetyltransferase enzymes (NATs), which catalyze the acetylation of arylamines as a detoxification mechanism, and are also expressed in breast cancer cells $[45,46]$. Thus it is difficult to predict whether the active form of the ferrocenyl compound is the amine, the amide, or both.
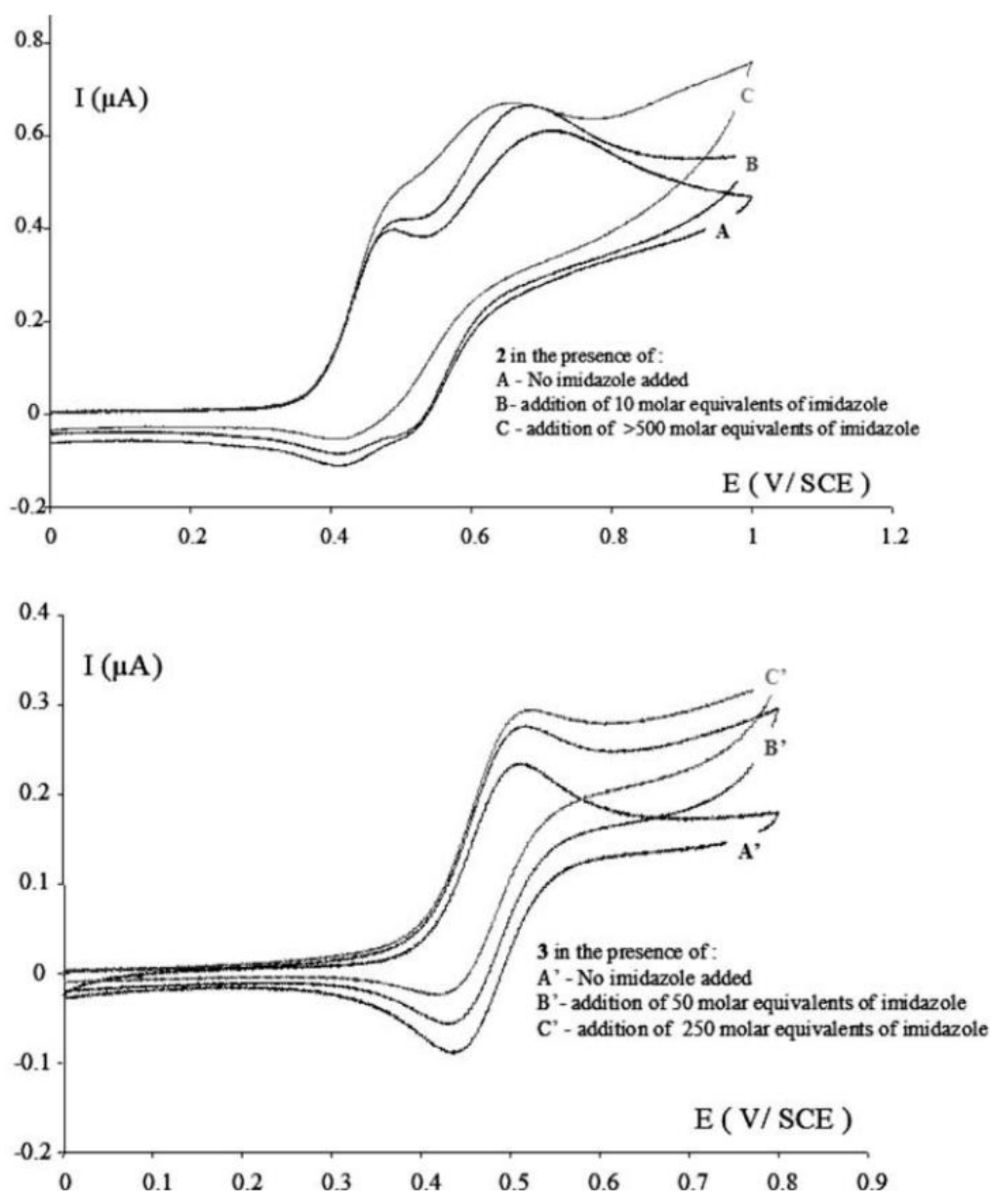

Fig. 4. Cyclic voltammograms for (a) 2 and (b) 3, in DMF. Pt (0.5 mm) working electrode, platinum mesh counter electrode, SCE reference electrode, scan rate $=100 \mathrm{mV} / \mathrm{s}$. For $\mathbf{2}$, the first wave corresponds to the ferrocene oxidation, while the second corresponds to the amine oxidation.

\subsection{Electrochemistry}

Electrochemical results suggest that both $\mathbf{2}$ and $\mathbf{3}$ can be transformed into potentially toxic oxidized products via the previously proposed ferricenium-mediated proton-coupled electron transfer mechanism; the cyclic voltammograms in DMF and DMF/imidazole are shown in Fig. 4. A characteristic feature of this mechanism is a base-dependent enhancement of the wave appearing at the ferrocene oxidation potential, coupled with loss of reversibility, demonstrating electron transfer from the organic part of the molecule to the electrochemically-generated ferricenium moiety. The addition of imidazole enhanced the 
intensity and irreversibility of this wave for both compounds. The base-promoted electron transfer in compound $\mathbf{2}$ is further evidenced by the decrease in intensity and potential of the oxidation wave of the amino group at $0.7 \mathrm{~V}$ upon addition of a base. This reveals the transition of an amino group to an aminyl radical triggered by the oxidation of the ferrocene at the first wave. In Fig. 4b, this is not apparent, because the amide oxidation wave lies outside the displayed window.

Electronic communication between a ferrocene group and an electrode via a conjugated system has been previously demonstrated by electron exchange when such compounds are anchored by a sulfur atom to a Au electrode [47]. This communication is very fast $\left(\mathrm{t}_{1 / 2} \mathrm{ca} .0 .5\right.$ $\mu \mathrm{s})$, compared to the scan rates we use in this report, and thus an equilibrium between the ferrocene-centered radical cation and the phenol-centered radical cation is reached essentially immediately. When the substituted phenyl radical cation can react (for example with a base present in the system), this equilibrium acts as an activation barrier for the overall reaction, such that, according to the Hammond postulate, the rate can be described as $k=k_{0} \exp (-$ $\Delta G^{\circ} / \mathrm{RT}$ ), where $k_{0}$ is the intrinsic rate constant of the deprotonation step and $\Delta G^{\circ}>0$, the free Gibbs energy difference between the two forms of the cation radical of the molecule, as shown in Scheme 3.

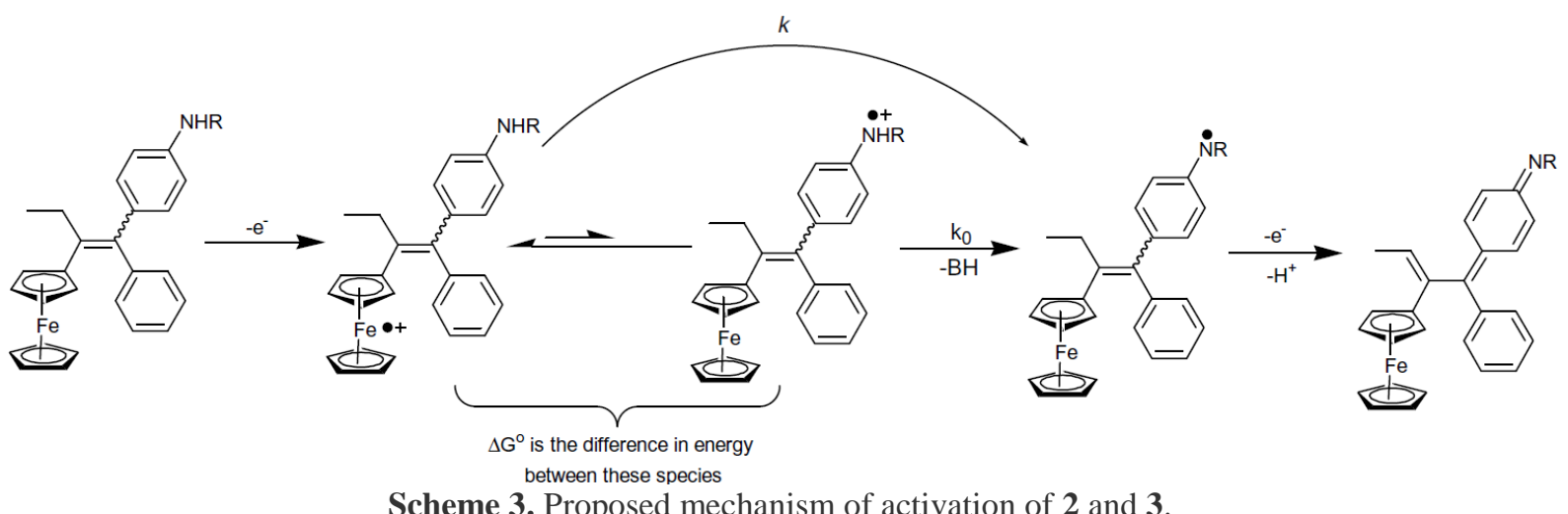

Scheme 3. Proposed mechanism of activation of $\mathbf{2}$ and $\mathbf{3 .}$

The oxidation potential of the functional group is related to the position of the equilibrium and the height of the activation barrier, $\Delta G^{\circ}$. Due to the electron withdrawing character of the acetyl group, the oxidation of anilines occurs at less positive potentials than those of acetanilides [48-50], thus $\Delta G^{\circ}$ would be expected to be larger in the case of $\mathbf{3}$ compared to 2 . In our experiments, we found that the irreversible oxidation wave of the amino group in the organic molecule 4 occurred at $+0.84 \mathrm{~V}$ (vs. SCE) and that of the amido group in $\mathbf{5}$ occurred irreversibly at $+1.40 \mathrm{~V}$. On the other hand, the value of $k_{0}$ will be influenced by the acidity of the amine or acetamide radical cation. The radical cation of phenylamine is very reactive [51], and that of acetanilide likely even more so, considering the difference in their $\mathrm{pKa}$ values (aniline $=30.6$, aniline radical cation $=6.4$ [52] and acetanilide $=21.45$, acetanilide radical cation $=-5$ [53]). A recent electrochemical study demonstrated that 2 could be covalently bonded to an electrode surface through the nitrogen atom by electrolysis at the ferrocene oxidation potential $(+0.4 \mathrm{~V})$ in the presence of 2,4,6-pyridine [28]. This clearly demonstrates an intramolecular electron transfer for 2 even in the presence of a weak base. Due to the similarity of the CVs, it appears that the high $k_{0}$ value for [3]+ may be enough to compensate for the much smaller value of $\exp \left(-\Delta G^{\circ} / \mathrm{RT}\right)$, compared to 2 , although further experiments will have to be carried out to address this point.

In terms of the putative active agent, imino methides are known [54], and indeed have been implicated in cytotoxic processes [55-60]. However, while acetylated quinone imines are also important toxic metabolites, for example of the Parkinson's disease drug tolcapone [48] and 
the analgesic acetaminophen [61], acetylated imine methides are rare. To our knowledge, the only evidence of an acetylated $p$-imine methide was a short lived species $(1 \mathrm{~ms})$ generated from laser flash photolysis of 4-acetylaminostilbene [62]. These compounds are probably less stable due to the electron withdrawing acetyl group, because donation of the nitrogen atom $\pi$ electrons into the ring favors the participation of the quinoid form over the aromatic form [63]. We are currently attempting to isolate the oxidation products of $\mathbf{2}$ and $\mathbf{3}$ and examine their reactivity with nucleophiles such as glutathione.

\section{Conclusion}

We have demonstrated that the oxidative activation of ferrocenyl compounds to toxic species is not limited to the series of ferrocenyl phenols. The ferrocenyl aniline 2 and acetanilide 3 showed estrogenic activity on the ER + MCF-7 breast cancer cell line, due to their affinity for the estrogen receptor, and a pronounced cytotoxicity against the ER-MDAMB-231 breast cancer cell line. Notably, the purely organic aniline $\mathbf{4}$ and acetanilide 5 did not give rise to cytotoxic effects. The mechanism of activation seems to follow the intramolecular electron transfer process previously observed for the series of conjugated ferrocenyl $p$ phenols. This study thus broadens the perspectives for useful functional groups in the design of redox activated cancer drug candidates.

\section{Experimental}

\subsection{General remarks}

The synthesis of all compounds was performed under an argon atmosphere, using standard Schlenk techniques. Anhydrous THF was obtained by distillation from sodium/benzophenone. Thin layer chromatography was performed on silica gel 60 GF254. Infrared spectra were obtained on an IR-FT BOMEM Michelson-100 spectrometer equipped with a DTGS detector as a $\mathrm{KBr}$ plate. ${ }^{1} \mathrm{H}$ and ${ }^{13} \mathrm{C}$ NMR spectra were recorded on a $300 \mathrm{MHz}$ Bruker spectrometer. Mass spectrometry was performed with a Nermag R 10-10C spectrometer. High resolution mass spectrometry (HRMS) was performed on a JEOL MS 700 instrument. Melting points were measured with a Kofler device. Elemental analyses were performed by the microanalysis service of CNRS at Gif sur Yvette. The semi-preparative HPLC separations were performed on a Shimadzu apparatus with a Kromasil C18 column (length of $25 \mathrm{~cm}$, diameter of $2 \mathrm{~cm}$, and particle size of $10 \mu \mathrm{m}$ ). Cyclic voltammograms were obtained utilizing a Princeton Applied Research potentiostat. Analyte solutions were $1 \mathrm{mM}$ in DMF with $0.1 \mathrm{M} \mathrm{Bu}_{4} \mathrm{NBF}_{4}$ supporting electrolyte. Cyclic voltammetry experiments were performed at room temperature under an argon atmosphere in a three-electrode cell. The reference electrode was an SCE (Tacussel), which was separated from the solution by a bridge compartment filled with the same solvent/supporting electrolyte solution as used in the cell. The counter electrode was a platinum mesh (Goodfellow). The platinum working electrode was home-made $(0.5 \mathrm{~mm}$ diameter; Goodfellow).

\subsection{Synthesis and characterization of compounds}

\subsubsection{2-Ferrocenyl-1-(4-aminophenyl)-1-phenyl-but-1-ene, $(Z+E)-2$}

The synthesis of $\mathbf{2}$ via the reaction between propionyl ferrocene and 4-aminobenzophenone was reported in Ref. [28]. 
4.2.1.1. Alternative pathway. Zn powder $(3.92 \mathrm{~g}, 60 \mathrm{mmol})$ was suspended in $30 \mathrm{~mL}$ of THF at $5-10{ }^{\circ} \mathrm{C}$ in a Schlenk tube under argon. While stirring, $\mathrm{TiCl}_{4}(5.69 \mathrm{~g}, 30 \mathrm{mmol})$ was added slowly via a syringe. The reaction mixture was removed from the cold bath and refluxed for $1 \mathrm{~h} 30$. To the reaction mixture was added $15 \mathrm{~mL}$ of a THF solution containing propionyl ferrocene $(2.42 \mathrm{~g}, 10 \mathrm{mmol})$ and 4-nitrobenzophenone $(2.27 \mathrm{~g}, 10 \mathrm{mmol})$, and reflux conditions were maintained for $4 \mathrm{~h}$. The reaction mixture was poured into $100 \mathrm{~mL}$ of water, and extracted with $3 \times 100 \mathrm{~mL}$ of dichloromethane. The organic phase was washed with 100 $\mathrm{mL}$ of water, dried over magnesium sulfate, filtered, and the solvent was evaporated. The brown oil was purified on a silica gel column using dichloromethane as an eluent. Compound 2 (1.31 g, 54\% yield) was recrystallized from ethanol to give a mixture of $Z$ and $E$ isomers (45/55, major isomer was not identified). The yield varies significantly from one batch of 4nitrobenzophenone to another.

\subsubsection{2-Ferrocenyl-1-(4-acetylaminophenyl)-1-phenyl-but-1-ene, 3}

In a Schlenk flask under argon, $2(407 \mathrm{mg}, 1 \mathrm{mmol})$ was dissolved in $15 \mathrm{~mL}$ of anhydrous THF. Acetyl chloride (78 mg, $1 \mathrm{mmol})$ and pyridine $(79 \mathrm{mg}, 1 \mathrm{mmol})$ were added and the reaction mixture was stirred for $3 \mathrm{~h}$. Water $(50 \mathrm{~mL})$ was added and the product was extracted with dichloromethane $(3 \times 50 \mathrm{~mL})$. The organic phase was washed with $50 \mathrm{~mL}$ of water, dried over magnesium sulfate, filtered, and the solvent was evaporated. The product was purified on a silica gel column with ether/pentane (1/1) as the eluent. Compound $\mathbf{3}$ was obtained as a brown oil (372 mg, 91\% yield) consisting of a mixture of $Z$ and $E$ isomers (60/40, respectively). The

identity of the major $(Z)$ isomer was determined by 2D NMR.

(Z)-3: ${ }^{1} \mathrm{H}$ NMR $\left(300 \mathrm{MHz}, \mathrm{DMSO}-d_{6}\right): \delta 1.00\left(\mathrm{t}, J=7.5 \mathrm{~Hz}, 3 \mathrm{H}, \mathrm{CH}_{3}\right), 2.02(\mathrm{~s}, 3 \mathrm{H}$, $\mathrm{CH}_{3} \mathrm{CO}$ ), 2.47 (q, $\left.J=7.5 \mathrm{~Hz}, 2 \mathrm{H}, \mathrm{CH}_{2}\right), 3.82\left(\mathrm{t}, J=1.0 \mathrm{~Hz}, 2 \mathrm{H}, \mathrm{C}_{5} \mathrm{H}_{4}\right), 4.11(\mathrm{t}, J=1.0 \mathrm{~Hz}$, $\left.2 \mathrm{H}, \mathrm{C}_{5} \mathrm{H}_{4}\right), 4.13\left(\mathrm{~s}, 5 \mathrm{H}, \mathrm{C}_{5} \mathrm{H}_{5}\right), 6.99\left(\mathrm{~d}, J=8.5 \mathrm{~Hz}, 2 \mathrm{H}, \mathrm{H}_{\text {arom }}\right), 7.22\left(\mathrm{~m}, 3 \mathrm{H}, \mathrm{H}_{\text {arom }}\right), 6.99(\mathrm{t}, J=$ $\left.8.5 \mathrm{~Hz}, 2 \mathrm{H}, \mathrm{H}_{\text {arom }}\right), 7.46\left(\mathrm{~d}, J=8.5 \mathrm{~Hz}, 2 \mathrm{H}, \mathrm{H}_{\text {arom }}\right), 9.89(\mathrm{~s}, 1 \mathrm{H}, \mathrm{NH}) ;{ }^{13} \mathrm{C} \mathrm{NMR}(75 \mathrm{MHz}$, DMSO-d $\left.d_{6}\right): \delta 15.3\left(\mathrm{CH}_{3}\right), 23.9\left(\mathrm{CH}_{3} \mathrm{CO}\right), 27.0\left(\mathrm{CH}_{2}\right), 68.0\left(\mathrm{C}_{5} \mathrm{H}_{4}\right), 68.7\left(\mathrm{C}_{5} \mathrm{H}_{4}\right), 69.0\left(\mathrm{C}_{5} \mathrm{H}_{5}\right)$, $85.4\left(\mathrm{C} \mathrm{C}_{5} \mathrm{H}_{4}\right), 118.9\left(2 \mathrm{CH}_{\text {arom }}\right), 126.1\left(\mathrm{CH}_{\text {arom }}\right), 128.3\left(2 \mathrm{CH}_{\text {arom }}\right), 128.7\left(2 \mathrm{CH}_{\text {arom }}\right), 129.4$ (2 $\mathrm{CH}_{\text {arom }}$ ), $136.6(\mathrm{C}), 136.9$ (C), 137.5 (C), 139.0 (C), 144.3 (C), $168.1(\mathrm{CO})$.

$(E)-3:{ }^{1} \mathrm{H}$ NMR $\left(300 \mathrm{MHz}, \mathrm{DMSO}-d_{6}\right): \delta 1.00\left(\mathrm{t}, J=7.5 \mathrm{~Hz}, 3 \mathrm{H}, \mathrm{CH}_{3}\right), 2.06(\mathrm{~s}, 3 \mathrm{H}$, $\mathrm{CH}_{3} \mathrm{CO}$ ), $2.47\left(\mathrm{q}, J=7.5 \mathrm{~Hz}, 2 \mathrm{H}, \mathrm{CH}_{2}\right), 3.80\left(\mathrm{t}, J=1.0 \mathrm{~Hz}, 2 \mathrm{H}, \mathrm{C}_{5} \mathrm{H}_{4}\right), 4.10(\mathrm{t}, J=1.0 \mathrm{~Hz}$, $\left.2 \mathrm{H}, \mathrm{C}_{5} \mathrm{H}_{4}\right), 4.13\left(\mathrm{~s}, 5 \mathrm{H}, \mathrm{C}_{5} \mathrm{H}_{5}\right), 7.08\left(\mathrm{~d}, J=8.5 \mathrm{~Hz}, 2 \mathrm{H}, \mathrm{H}_{\text {arom }}\right), 7.15\left(\mathrm{~d}, J=8.5 \mathrm{~Hz}, 2 \mathrm{H}, \mathrm{H}_{\text {arom }}\right)$, $7.26\left(\mathrm{~m}, 3 \mathrm{H}, \mathrm{H}_{\text {arom }}\right), 7.54\left(\mathrm{~d}, J=8.5 \mathrm{~Hz}, 2 \mathrm{H}, \mathrm{H}_{\text {arom }}\right), 9.93(\mathrm{~s}, 1 \mathrm{H}, \mathrm{NH}) ;{ }^{13} \mathrm{C} \mathrm{NMR}(75 \mathrm{MHz}$, DMSO-d $\left.d_{6}\right): \delta 15.3\left(\mathrm{CH}_{3}\right), 23.9\left(\mathrm{CH}_{3} \mathrm{CO}\right), 27.0\left(\mathrm{CH}_{2}\right), 68.0\left(\mathrm{C}_{5} \mathrm{H}_{4}\right), 68.7\left(\mathrm{C}_{5} \mathrm{H}_{4}\right), 69.0\left(\mathrm{C}_{5} \mathrm{H}_{5}\right)$, $85.4\left(\mathrm{C} \mathrm{C}_{5} \mathrm{H}_{4}\right), 118.9\left(2 \mathrm{CH}_{\text {arom }}\right), 126.1\left(\mathrm{CH}_{\text {arom }}\right), 128.3\left(2 \mathrm{CH}_{\text {arom }}\right), 128.9\left(2 \mathrm{CH}_{\text {arom }}\right), 129.1$ (2 $\mathrm{CH}_{\text {arom}}$ ), 136.6 (C), 136.9 (C), 137.5 (C), 139.0 (C), 144.3 (C), 168.1 (CO).

The product was recrystallized from a mixture of ether/pentane to give the pure $Z$ isomer: M.p.: $206{ }^{\circ} \mathrm{C}$; Rf: 0.35 (ether/pentane = 1/1); IR $\left(\mathrm{KBr}, v \mathrm{~cm}^{-1}\right)$ : $1656(\mathrm{CON})$; MS (EI, $\left.70 \mathrm{eV}\right)$ m/z: $449[\mathrm{M}]^{+}, 407,384\left[\mathrm{M}-\mathrm{C}_{5} \mathrm{H}_{5}\right]^{+}, 342,326,121\left[\mathrm{FeC}_{5} \mathrm{H}_{5}\right]^{+}$; Anal. Calc. for $\mathrm{C}_{28} \mathrm{H}_{27} \mathrm{FeNO}$ : C, 74.84; H, 6.06; N, 3.12. Found: C, 74.82; H, 5.85; N, 3.02\%.

\subsubsection{1-(4-Aminophenyl)-1,2-bis-phenyl-but-1-ene, $(Z+E)-4$}

Zinc powder (3.92 g, $60 \mathrm{mmol})$ was suspended in $30 \mathrm{ml}$ of THF at $5-10{ }^{\circ} \mathrm{C}$ in a Schlenk tube under argon. While stirring, titanium tetrachloride $(5.69 \mathrm{~g}, 30 \mathrm{mmol})$ was added slowly via a syringe. The reaction mixture was removed from the cold bath and refluxed for $1 \mathrm{~h} 30$. To the reaction mixture was added $15 \mathrm{~mL}$ of a THF solution containing propiophenone $(1.34 \mathrm{~g}$, $10 \mathrm{mmol})$ and 4-aminobenzophenone (1.97 $\mathrm{g}, 10 \mathrm{mmol})$, and reflux conditions were maintained for three days. The reaction mixture was poured into $100 \mathrm{~mL}$ of water, and extracted with $3 \times 100 \mathrm{~mL}$ of dichloromethane. The organic phase was washed with $100 \mathrm{~mL}$ 
of water, dried over magnesium sulfate, filtered, and the solvent was evaporated. The oil was purified on a silica gel column using dichloromethane as an eluent. Compound $\mathbf{4}$ was obtained as an $85 / 15$ mixture of $Z$ and $E$ isomers (major isomer was not identified) and was recrystallized from ethanol; Yield $38 \%$.

4.2.3.1. Alternative pathway. The synthesis was identical to the alternative pathway of $\mathbf{2}$, except that propiophenone $(0.134 \mathrm{~g}, 1 \mathrm{mmol})$ was used in place of propionyl ferrocene, to furnish a mixture of $Z$ and $E$ isomers (85/15); Yield 55\%. As for 2 the yield varies greatly with the batch of 4-nitrobenzophenone used.

${ }^{1} \mathrm{H} \mathrm{NMR}\left(300 \mathrm{MHz}, \mathrm{CDCl}_{3}\right): \delta 0.84$ and $0.87\left(\mathrm{t}, J=7.4 \mathrm{~Hz}, 3 \mathrm{H}, \mathrm{CH}_{3}\right), 2.37$ and 2.45 (q, $J$ $\left.=7.4 \mathrm{~Hz}, 2 \mathrm{H}, \mathrm{CH}_{2}\right), 4.29\left(\mathrm{~s}\right.$ broad, $\left.2 \mathrm{H}, \mathrm{NH}_{2}\right), 6.34$ and $6.65\left(\mathrm{~d}, J=8.5 \mathrm{~Hz}, 2 \mathrm{H}, \mathrm{H}_{\text {arom }}\right), 6.60$ and $6.95\left(\mathrm{~d}, J=8.5 \mathrm{~Hz}, 2 \mathrm{H}, \mathrm{H}_{\text {arom }}\right), 6.70-7.35\left(\mathrm{~m}, 10 \mathrm{H}, \mathrm{H}_{\text {arom }}\right) ;{ }^{13} \mathrm{C} \mathrm{NMR}\left(75 \mathrm{MHz}, \mathrm{CDCl}_{3}\right): \delta$ $13.6\left(\mathrm{CH}_{3}\right), 29.0\left(\mathrm{CH}_{2}\right), 114.4$ and $114.9\left(2 \mathrm{CH}_{\text {arom }}\right), 125.5$ and $125.9\left(\mathrm{CH}_{\text {arom }}\right), 125.9$ and $126.4\left(\mathrm{CH}_{\text {arom }}\right), 127.2$ and $127.8\left(2 \mathrm{CH}_{\text {arom }}\right), 127.7$ and $128.0\left(2 \mathrm{CH}_{\text {arom }}\right), 129.5$ and $129.7(2$ $\left.\mathrm{CH}_{\text {arom }}\right), 129.7$ and $130.5\left(2 \mathrm{CH}_{\text {arom }}\right), 130.9$ and $131.8\left(2 \mathrm{CH}_{\text {arom }}\right), 133.8$ and $134.3(\mathrm{C}), 138.5$ and $138.7(\mathrm{C}), 140.6$ and $141.5(\mathrm{C}), 142.6$ and $142.7(\mathrm{C}), 143.6(\mathrm{C}), 144.0$ and $144.6(\mathrm{C})$; IR $\left(\mathrm{KBr}, v \mathrm{~cm}^{-1}\right): 3474,3380\left(\mathrm{NH}_{2}\right), 3077,3025,2959,2929,2870\left(\mathrm{CH}_{2}, \mathrm{CH}_{3}\right) ; \mathrm{MS}(\mathrm{EI}, 70 \mathrm{eV})$

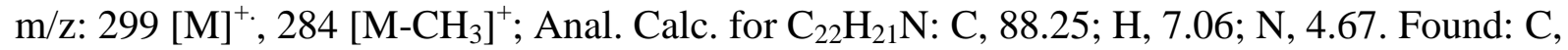
88.09; H, 7.09; N, 4.66\%.

\subsubsection{1-(4-N-acetamidophenyl)-1,2-bis-phenyl-but-1-ene, (E+Z)-5}

The synthesis was identical to that of 3, except that compound $(Z+E)-4(0.299 \mathrm{~g}, 1 \mathrm{mmol})$ was used in place of compound $(Z+E)-2$, to furnish a mixture of $Z$ and $E$ isomers $(85 / 15)$. After recrystallization from ethanol, the ratio was $95 / 5$; Yield $81 \%$.

${ }^{1} \mathrm{H}$ NMR $\left(300 \mathrm{MHz}\right.$, acetone- $\left.d_{6}\right): \delta 0.95$ and $0.97\left(\mathrm{t}, J=7.4 \mathrm{~Hz}, 3 \mathrm{H}, \mathrm{CH}_{3}\right), 2.03$ and 2.12 (s, 3H, $\mathrm{CH}_{3} \mathrm{CO}$ ), 2.50 and $2.55\left(\mathrm{q}, J=7.4 \mathrm{~Hz}, 2 \mathrm{H}, \mathrm{CH}_{2}\right), 6.77-7.75\left(\mathrm{~m}, 14 \mathrm{H}, \mathrm{H}_{\text {arom }}\right), 9.0$ and 9.22 (s broad, $1 \mathrm{H}, \mathrm{NH}) ;{ }^{13} \mathrm{C}$ NMR $\left(75 \mathrm{MHz}\right.$, acetone- $\left.d_{6}\right): \delta 13.7\left(\mathrm{CH}_{3}\right), 24.2\left(\mathrm{CH}_{3} \mathrm{CO}\right), 29.5$ $\left(\mathrm{CH}_{2}\right), 118.7$ and $118.8\left(2 \mathrm{CH}_{\text {arom }}\right), 126.6$ and $127.0\left(\mathrm{CH}_{\text {arom }}\right), 127.0$ and $127.5\left(\mathrm{CH}_{\text {arom }}\right), 128.2$ and $128.7\left(2 \mathrm{CH}_{\text {arom }}\right), 128.6$ and $129.0\left(2 \mathrm{CH}_{\text {arom }}\right), 130.1$ and $130.4\left(2 \mathrm{CH}_{\text {arom }}\right), 130.5$ (2 $\left.\mathrm{CH}_{\text {arom}}\right), 131.4$ and 131.7 (2 $\left.\mathrm{CH}_{\text {arom }}\right), 138.4(\mathrm{C}), 138.7$ (C), 139.5 (C), 142.5 (C), 143.2 (C), $144.5(\mathrm{C}), 168.6(\mathrm{CON})$; IR (KBr, $\left.v \mathrm{~cm}^{-1}\right): 3458,3294,3251(\mathrm{NH}), 3103,3045,2969,2929$, $2865\left(\mathrm{CH}_{2}, \mathrm{CH}_{3}\right), 1663$ (CON); HRMS (EI, $\left.70 \mathrm{eV}, \mathrm{C}_{24} \mathrm{H}_{23} \mathrm{NO}: \mathrm{M}^{+}\right)$Calc.: 341.1780. Found: 341.1776 .

\subsection{Biochemical studies}

\subsubsection{Materials}

Stock solutions $\left(10^{-3} \mathrm{M}\right.$ and $\left.10^{-2} \mathrm{M}\right)$ of the compounds to be tested were prepared in DMSO and were kept at $-20{ }^{\circ} \mathrm{C}$. Under these conditions, they are stable at least 2 weeks. Serial dilutions

in DMSO were prepared just prior to use. Dulbecco's Modified Eagle Medium (DMEM), fetal calf serum, glutamine and kanamycine were purchased from Invitrogen (France), estradiol and protamine sulfate were from Sigma-Aldrich (France). Breast cancer cells MCF7 (hormone-dependent) and MDA-MB231 (hormone-independent) were from the American Type Culture Collection (ATCC - LGC Promochem). Sheep uteri weighing approximately 7 $\mathrm{g}$, were obtained

from the slaughterhouse at Mantes-la-Jolie, France. They were immediately frozen and kept in liquid nitrogen prior to use. ER $\beta$ PanVera were purchased from Invitrogen (France). 
RBA values were measured on ER $\alpha$ from lamb uterine cytosol and on purified ER $\beta$ (PanVera). Sheep uterine cytosol prepared in buffer A (0.05 M Tris-HCL, 0.25 M sucrose, $0.1 \% \beta$-mercaptoethanol, $\mathrm{pH} 7.4$ at $25{ }^{\circ} \mathrm{C}$ ) as previously described [64] was used as a source of ER $\alpha$. For ER $\beta, 10 \mu \mathrm{L}$ of the solution containing $3500 \mathrm{pmol} / \mathrm{mL}$ were added to $10 \mathrm{~mL}$ of buffer B (10\% glycerol, $50 \mathrm{mM}$ Bis-Tris-propane pH $9400 \mathrm{mM} \mathrm{KCl,} 2 \mathrm{mM}$ DTT, $1 \mathrm{mM}$ EDTA, $0.1 \% \mathrm{BSA})$. Aliquots $(200 \mu \mathrm{L})$ of ER $\alpha$ in glass tubes or ER $\beta$ in polypropylene tubes were incubated for $3 \mathrm{~h} 30$ at $0{ }^{\circ} \mathrm{C}$ with $\left[6,7-{ }^{3} \mathrm{H}\right]$-estradiol $\left(2 \times 10^{-9} \mathrm{M}\right.$, specific activity 1.62 $\mathrm{TBq} / \mathrm{mmol}$, NEN Life Science Product) in the presence of nine concentrations of the compounds to be tested (between $6 \times 10^{-7} \mathrm{M}$ and $6 \times 10^{-9} \mathrm{M}$ ) or of non-radioactive $\mathrm{E}_{2}$ (between $8 \times 10^{-8} \mathrm{M}$ and $8 \times 10^{-10} \mathrm{M}$ ). At the end of the incubation period, the free and bound fractions of the tracer were separated by protamine sulfate precipitation. The percentage reduction in binding of $\left[{ }^{3} \mathrm{H}\right]$-estradiol $(Y)$ was calculated using the logit transformation of $Y$ (logit $Y: \ln [y / 1-Y]$ vs. the $\log$ of the mass of the competing steroid. The concentration of unlabeled steroid required to displace $50 \%$ of the bound $\left[{ }^{3} \mathrm{H}\right]$-estradiol was calculated for each steroid tested, and the results expressed as RBA. The RBA value of estradiol is by definition equal to $100 \%$.

\subsubsection{Culture conditions}

Cells were maintained in a monolayer culture in DMEM with phenol red/Glutamax I supplemented with $9 \%$ fetal bovine serum at $37{ }^{\circ} \mathrm{C}$ in a $5 \% \mathrm{CO}_{2}$ /air-humidified incubator. For proliferation assays, MCF-7 and MDA-MB-231 cells were plated in $1 \mathrm{~mL}$ of DMEM without phenol red, supplemented with 9\% decomplemented and hormone-depleted fetal bovine serum, $0.9 \%$ kanamycin, $0.9 \%$ Glutamax I and incubated. The following day (D0), $1 \mathrm{~mL}$ of the same medium containing the compounds to be tested was added to the plates. After 3 days (D3) the incubation medium was removed and $2 \mathrm{~mL}$ of the fresh medium containing the compounds was added. After 5 days the total protein content of the plate was analyzed as follows: cell monolayers were fixed for $1 \mathrm{~h}$ at room temperature with methylene blue $(1 \mathrm{mg}$ $\mathrm{mL}^{-1}$ in 50:50 water/MeOH mixture), then washed with water. After addition of $\mathrm{HCl}(0.1 \mathrm{M}, 2$ $\mathrm{mL}$ ), the plate was incubated for $1 \mathrm{~h}$ at $37{ }^{\circ} \mathrm{C}$ and then the absorbance of each well (three wells for each concentration) was measured at $655 \mathrm{~nm}$ with a Biorad microplate reader. The results are expressed as the percentage of proteins vs. the control. Experiments were performed at least in duplicate.

\subsection{Modeling studies}

Molecular modeling studies were carried out using the programs Spartan, Trident and Odyssey [65].

\section{Acknowledgements}

The authors thank Marie-Noelle Rager for the 2D NMR experiments and the Agence Nationale de la Recherche for financial support (No. ANR-06-BLAN-0384-01, "FerVect").

\section{References}

[1] P. Kovacic, Med. Hypotheses 69 (2007) 510.

[2] E.A. Hillard, F.C. de Abreu, D.C. Ferreira, G. Jaouen, M.O. Goulart, C. Amatore, Chem. Commun. 23 (2008) 2612, and references therein.

[3] H. Pelicano, D. Carney, P. Huang, Drug Resist. Update 7 (2004) 97.

[4] P. Galfi, J. Jakus, T. Molnar, S. Neogrady, A. Csordas, J. Steroid Biochem. Mol. Biol. 94 (2005) 39. 
[5] M.E. Juan, U. Wenzel, H. Daniel, J.M. Planas, J. Agric. Food Chem. 56 (2008) 4813.

[6] V.C. Jordan, Tamoxifen for the Treatment and Prevention of Breast Cancer, PRR Inc., New York, 1999.

[7] P.W. Fan, F. Zhang, J.L. Bolton, Chem. Res. Toxicol. 13 (2000) 45, and references therein.

[8] S. Top, A. Vessières, C. Cabestaing, I. Laios, G. Leclercq, C. Provot, G. Jaouen, J. Organomet. Chem. 637 (2001) 500.

[9] A. Nguyen, A. Vessières, E.A. Hillard, S. Top, P. Pigeon, G. Jaouen, Chimia 61 (2007) 716.

[10] E. Allard, C. Passirani, E. Garcion, P. Pigeon, A. Vessières, G. Jaouen, J.P. Benoit, J. Control. Release 130 (2008) 146.

[11] A. Vessières, S. Top, W. Beck, E.A. Hillard, G. Jaouen, Dalton Trans. 4 (2006) 529.

[12] G. Jaouen, S. Top, A. Vessières, G. Leclercq, M.J. McGlinchey, Curr. Med. Chem. 11 (2004) 2505.

[13] E.A. Hillard, P. Pigeon, A. Vessières, C. Amatore, G. Jaouen, Dalton Trans. (2007) 5073.

[14] E.A. Hillard, A. Vessières, F. Le Bideau, D. Plazuk, D. Spera, M. Huché, G. Jaouen, ChemMedChem 1 (2006) 551.

[15] E.A. Hillard, A. Vessières, L. Thouin, G. Jaouen, C. Amatore, Angew. Chem., Int. Ed. 45 (2006) 285.

[16] W.A. Wlassoff, C.D. Albright, M.S. Sivashinski, A. Ivanova, J.G. Appelbaum, R.I. Salganik, J. Pharm. Pharmacol. 59 (2007) 1549.

[17] M. Murata, M. Yamada, T. Fujita, K. Kojima, M. Kurihara, K. Kubo, Y. Kobayashi, H. Nishihara, J. Am. Chem. Soc. 123 (2001) 12903.

[18] S. Fukuzumi, K. Okamoto, Y. Yoshida, H. Imahori, Y. Araki, O. Ito, J. Am. Chem. Soc. 125 (2003) 1007.

[19] M. Kurihara, H. Sano, M. Murata, H. Nishihara, Inorg. Chem. 40 (2001) 4.

[20] M. Murata, T. Fujita, M. Yamada, M. Kurihara, H. Nishihara, Chem. Lett. 29 (2000) 1328.

[21] N.N. Meleshonkova, D.B. Shpakovsky, A.V. Fionov, A.V. Dolganov, T.V. Magdesieva, E.R. Milaeva, J. Organomet. Chem. 692 (2007) 5339.

[22] J.B. Heilmann, E.A. Hillard, M.-A. Plamont, P. Pigeon, M. Bolte, G. Jaouen, A. Vessières, J. Organomet. Chem. 693 (2008) 1716.

[23] S. Smith, D. Pasco, J. Pawlak, B. Thompson, M. Stampfer, S. Nandi, J. Natl. Cancer Inst. 73 (1984) 323.

[24] J. Shani, A. Gazit, T. Livshitz, S. Biran, J. Med. Chem. 28 (1985) 1504.

[25] J.E. McMurry, M.P. Fleming, J. Am. Chem. Soc. 96 (1974) 4708.

[26] A. Fürstner, B. Bogdanovic, Angew. Chem., Int. Ed. Engl. 35 (1996) 2442.

[27] B.E. Kahn, R.D. Rieke, Chem. Rev. 88 (1988) 733.

[28] O. Buriez, E. Labbé, P. Pigeon, G. Jaouen, C. Amatore, J. Electroanal. Chem. 619-620 (2008) 169.

[29] X.-F. Duan, J. Zeng, J.-W. Lü, Z.-B. Zhang, J. Org. Chem. 71 (2006) 9873.

[30] F.S. Zeelen, E.W. Bergink, in: J. Raus, H. Martens, G. Leclercq (Eds.), Cytotoxic Estrogens in Hormone Receptive Tumors, Academic Press, London, 1980, pp. 39-48.

[31] A.K. Shiau, D. Barstad, P.M. Loria, L. Cheng, P.J. Kushner, D.A. Agard, G.L. Greene, Cell 95 (1998) 927.

[32] A.K. Shiau, D. Barstad, J.T. Radek, M.J. Meyers, K.W. Nettles, B.S. Katzenellenbogen, J.A. Katzenellenbogen, D.A. Agard, G.L. Greene, Nat. Struct. Biol. 9 (2002) 359. 
[33] A. Vessières, S. Top, P. Pigeon, E.A. Hillard, L. Boubeker, D. Spera, G. Jaouen, J. Med. Chem. 48 (2005) 3937.

[34] J.L. Mott, G.J. Gores, Cancer Biol. Ther. 6 (2007) 97.

[35] R. Benigni, A. Giuliani, R. Franke, A. Gruska, Chem. Rev. 100 (2000) 3697.

[36] L. McLean, U. Soto, K. Agama, J. Francis, R. Jimenez, Y. Pommier, L. Sowers, E. Brantley, Int. J. Cancer 122 (2008) 1665.

[37] A. Fura, Drug Discov. Today 11 (2006) 133.

[38] M.R. Probst, M. Beer, D. Beer, P. Jeno, U.A. Meyer, R. Gasser, J. Biol. Chem. 269 (1994) 21650.

[39] T. Bisogno, K. Katayama, D. Melck, N. Ueda, L.D. Petrocellis, S. Yamamoto, V.D. Marzo, Eur. J. Biochem. 254 (1998) 634.

[40] A. Stañczak, A. Ferra, Pharmacol. Rep. 58 (2006) 599.

[41] J. Katz, M. Levitz, S.S. Kadner, T.H. Finlay, J. Steroid Biochem. Mol. Biol. 38 (1991) 17.

[42] Y. Kim, Y. Choi, R. Weissleder, C.-H. Tung, Bioorg. Med. Chem. Lett. 17 (2007) 5054

[43] J. Katz, T.H. Finlay, S. Banerjee, M. Levitz, J. Steroid Biochem. 26 (1987) 687.

[44] J.V. Watson, S.H. Chambers, P. Workman, T.S. Horsnell, FEBS Lett. 81 (1977) 179.

[45] J. Dairou, N. Atmane, F. Rodrigues-Lima, J.-M. Dupret, J. Biol. Chem. 279 (2004) 7708.

[46] J.A. Williams, D.H. Phillips, Cancer Res. 60 (2000) 4667.

[47] C. Amatore, E. Maisonhaute, B. Schöllhorn, J. Wadhawan, ChemPhysChem 8 (2007) 1321.

[48] K.S. Smith, P.L. Smith, T.N. Heady, J.M. Trugman, W.D. Harman, T.L. Macdonald, Chem. Res. Toxicol. 16 (2003) 123.

[49] E.M. Garrido, J.L.F.C. Lima, C. Delerue-Matos, F. Borges, A.M.S. Silva, J.A.P. Piedade, A.M.O. Brett, J. Agric. Food Chem. 51 (2003) 876.

[50] E.M. Garrido, J.L.F.C. Lima, C. Delerue-Matos, F. Borges, A.M.S. Silva, A.M.O. Brett, Anal. Chim. Acta 434 (2001) 35.

[51] P. Simon, G. Farsang, C. Amatore, J. Electroanal. Chem. 435 (1997) 165.

[52] F.G. Bordwell, X.-M. Zhang, J.-P. Cheng, J. Org. Chem. 58 (1993) 6410.

[53] F.G. Bordwell, D.J. Algrim, J. John, A. Harrelson, J. Am. Chem. Soc. 110 (1988) 5903.

[54] J. Nakayama, N. Matsumaru, M. Hoshino, Chem. Commun. 11 (1981) 565.

[55] J.C. Huijzer, J. James, D. Adams, G.S. Yost, Tox. Appl. Pharm. 90 (1987) 60.

[56] M.R. Nocerini, G.S. Yost, J.R. Carlson, D.J. Liberato, R.G. Breeze, Drug Metab. Dispos. 13 (1985) 690.

[57] F. Charmantray, A. Duflos, J. Lhommea, M. Demeunynck, J. Chem. Soc., Perkin Trans. 1 (2001) 2962.

[58] J.C. Powers, J. Oleksyszyn, S.L. Narasimhan, C.-M. Kam, R. Radhakrishnan, J.E.F. Meyer, Biochemistry 29 (1990) 3108.

[59] M.M. Chow, J. Edgar, F. Meyer, W. Bode, C.-M. Kam, R. Radhakrishnan, J. Vijayalakshmi, J.C. Powers, J. Am. Chem. Soc. 112 (1990) 7183.

[60] J.C. Powers, C.-M. Kam, L. Narasimhan, J. Oleksyszyn, M.A. Hernandez, T. Ueda, J. Cell Biochem. 39 (2004) 33.

[61] J.A. Hinson, A.B. Reid, S.S. McCullough, L.P. James, Drug Metab. Rev. 36 (2004) 805. and references therein.

[62] R. Bose, A.R. Ahmad, A.P. Dicks, M. Novak, K.J. Kayser, R.A. McClelland, J. Chem. Soc., Perkin Trans. 2 (1999) 1591.

[63] I.A. Morao, I.H. Hillier, Tetrahedron Lett. 42 (2001) 4429. 
[64] S. Top, A. Vessières, G. Leclercq, J. Quivy, J. Tang, J. Vaissermann, M. Huché, G. Jaouen, Chem. Eur. J. 9 (2003) 5223.

[65] Spartan, Trident, Odyssey, Wavefunction Inc., Irvine, CA 92612, USA. 